\title{
Protein-energy supplementation on productive and nutritional performance of grazing beef heifers
}

\section{A suplementação proteico-energética no desempenho produtivo e nutricional de novilhas de corte em pastejo}

\author{
Román Maza Ortega ; Deilen Sotelo Moreno*; Libardo Maza Angúlo³
}

\section{Highlights}

Our results evidence differences in productive performance.

Protein-energy supplementation increased CP and non-fibrous carbohydrates intake.

The higher nutrients input increased the concentration of serum urea nitrogen.

\begin{abstract}
This study was conducted with the aim of evaluating the effect of protein-energy supplementation on productive performance, intake, digestibility, and microbial protein synthesis in heifers fed tropical forage. Twelve Nellore heifers at 11 months of age, with a mean initial body weight of $248.8 \pm 11.40 \mathrm{~kg}$ were used. The animals were distributed in a completely randomized design with two treatments and six replicates. The treatments evaluated were: control (without supplementation); and supplementation in the amount of $1.5 \mathrm{~kg}$ animal $^{-1}$ day $^{-1}$. Forage samples were collected to evaluate the chemical composition and the total availability of dry matter of the pasture consumed by the animals. To evaluate the intake and forage digestibility, a trial was performed using internal and external markers. In this study no effect of supplementation was observed on the intakes of dry matter (DM), organic matter (OM), forage DM, or neutral detergent fiber corrected for ash and protein (NDFap; $P>0.10$ ). However, supplementation increased $(P<0.01)$ the intakes of crude protein $(C P)$, ether extract $(E E)$, and non-fibrous carbohydrates (NFC). Additionally, an upward trend $(P=0.076)$ was observed in the intake of digested OM (DOM) with supplementation. On the other hand, supplementation increased $(P<0.01)$ the digestibility coefficients of $O M, C P, E E$, and NFC, although supplementation did not affect the ruminal synthesis of nitrogen compounds (MICN), efficiency of protein microbial synthesis (EMS), relative microbial nitrogen (RMICN) or urine urea nitrogen (UUN) excretion $(P>0.57)$. Lastly, supplementation increased $(P=0.050)$ the average daily gain of the animals, although no effect $(P>0.10)$ was observed on their final body weight. These results suggested that protein-energy supplementation improves the productive performance and nutritional characteristics of grazing beef heifers.
\end{abstract}

Key words: Animal nutrition. Cattle. Digestibility. Tropical pasture. Urea nitrogen. Voluntary intake.

1 Prof. Dr., Universidad de Pamplona, UP, Departamento de Zootecnia, Pamplona, Norte de Santander, Colômbia. E-mail: rmaza777@hotmail.es

2 Prof. Dr., Universidad de Pamplona, UP, Departamento de Medicina Veterinária, Pamplona, Norte de Santander, Colômbia.E-mail: deilen.sotelo@unipamplona.edu.co

3 Prof. M.e, Universidad de Córdoba, UNICOR, Departamento de Ciências da Pecuária, Montería, Córdoba, Colômbia. E-mail: libardomaza@gmail.com

* Author for correspondence

Received: June 12, 2021 - Approved: Nov. 03, 2021 


\section{Resumo}

Este estudo foi conduzido com o objetivo de avaliar o efeito da suplementação proteico-energético sobre o desempenho produtivo, consumo, digestibilidade e sínteses de proteína microbiana em novilhas de corte alimentadas com forragem tropical. Doze novilhas Nelore com 11 meses de idade e peso corporal médio inicial de $248,8 \pm 11,40 \mathrm{~kg}$ foram utilizadas. Os animais foram distribuídos em delineamento inteiramente casualizado com dois tratamentos e seis repetições. Os tratamentos avaliados foram: controle (não suplementado); e suplementado na quantidade de 1,5 kg animal-1 dia-1. Amostras de forragem foram coletadas para avaliar a composição química e a disponibilidade total de matéria seca do pasto consumido pelos animais. Para avaliar o consumo e digestibilidade da forragem, um ensaio foi conduzido usando marcadores internos e externos. Neste estudo não foi observado efeito da suplementação sobre o consumo de matéria seca (MS), matéria orgânica (MO), MS da forragem, ou fibra em detergente neutro corrigida para cinzas e proteína (FDNcp; P > 0,10). No entanto, a suplementação incrementou o consumo de proteína bruta $(\mathrm{PB})$, extrato etéreo (EE) e carboidratos não fibrosos (CNF). Além disso, foi observada uma tendência de aumento $(P=0,076)$ no consumo de $M O$ digerida $(M O D)$ com a suplementação. Por outro lado, a suplementação aumentou $(P<0,01)$ os coeficientes de digestibilidade da $M O, P B, E E$ e CNF, embora a suplementação não tenha afetado a síntese ruminal de compostos nitrogenados (NMIC), eficiência de síntese de proteína microbiana (EFM), nitrogênio microbiano relativo (NMICR) ou excreção de nitrogênio ureico na urina (NUU) $(P>0,57)$. Finalmente, a suplementação aumentou $(P<0,050)$ o ganho médio diário dos animais, embora nenhum efeito $(P>0,10)$ tenha sido observado no peso corporal final. Esses resultados sugerem que a suplementação proteico-energética melhora o desempenho produtivo e as características nutricionais de novilhas de corte em pastejo.

Palavras-chave: Consumo voluntario. Digestibilidade. Gado. Nitrogênio ureico. Nutrição animal. Pastagem tropical.

\section{Introduction}

Most Brazilian beef cattle production systems have used tropical grasses as basal forage resources, as they provide low-cost energy from the potentially digestible fraction of neutral detergent fiber (NDF) (Detmann, Gionbelli, Paulino, Valadares, \& Rennó, 2016). However, the tropical grasses are rarely available as a balanced diet for grazing cattle because they invariably exhibit a nutritional constraint, related to the contents of NDF, $\mathrm{CP}$ and energy, and energy to protein ratio, that will limit pasture intake and digestibility. As a consequence, grazing cattle usually receive imbalanced nutrition both in terms of quality and quantity from the forage, resulting in suboptimal animal performance, which ultimately leads to a decrease in the bioeconomic efficiency of the beef cattle farming activity (Detmann et al., 2016; Detmann, Paulino, Valadares, \& Huhtanen, 2014a).

In this context, there is a demand to identify the main nutritional limitation of tropical pasture to avoid production constraints. After being identified, nutritional deficiencies can be reduced or even eliminated through an adequate supplementation program, improving the performance of grazing cattle and the efficiency of the production system (Detmann et al., 2014a). 
Protein-energy supplementation with nitrogen compounds for grazing cattle is considered the main tools to overcome dietary and nutrient deficiencies of tropical grasses (Detmann, Valente, Batista, \& Huhtanen, 2014b), since they improve the digestibility, intake of forage DM and metabolic efficiency, leading to increased utilization of the energy from forage. Protein-energy supplementation allows an additional daily gain of $200 \mathrm{~g}$ animal- 1 when compared with no supplementation, in grazing animals (Almeida et al., 2018).

Thus, it was hypothesized that proteinenergy supplementation may improve the production performance and nutritional characteristics of grazing cattle. In this way, the present study was performed to evaluate the effect of protein-energy supplementation of grazing beef heifers on productive performance, and nutritional characteristics.

\section{Materials and Methods}

All the procedures performed on the animals were approved by the Institutional Animal Care and Use Committee of Universidade Federal de Viçosa (protocol CEUAP-UFV number 10/2016).

\section{Location}

This experiment was carried out at the Department of Animal Science of Universidade Federal de Viçosa, Brazil, located at $20^{\circ} 45^{\prime} 45^{\prime \prime}$ S latitude and $42^{\circ} 52^{\prime} 04^{\prime \prime}$ W longitude; $657 \mathrm{~m}$ altitude, between October and January, which corresponded to the dryrainy transition season. Average temperature and precipitation values of $22.4^{\circ} \mathrm{C}$ and 144.9 $\mathrm{mm}$ were observed during the experimental period.

Animal, experimental design, and diets

Twelve Nellore heifers with ages and initial mean weights of 11 months and $248.8 \pm 11.40 \mathrm{~kg}$ of body weight (BW), respectively, were used. The animals were distributed in a completely randomized design with two treatments and six replicates. The treatments evaluated were: control (without supplementation); and supplementation in the amount of $1.5 \mathrm{~kg}$ animal-1 day- 1 . The supplement was composed of ground corn, ground sorghum, soybean meal, and cottonseed meal and balanced to contain $25 \% \mathrm{CP}$ as fed (Table 1). All the animals received a mineral salt in the amount de $75 \mathrm{~g}$ animal $^{-1}$ day $^{-1}$, being composed of dicalcium phosphate, $500 \mathrm{~g} / \mathrm{kg}$; sodium chloride, 471.9 g/kg; zinc sulfate, $15 \mathrm{~g} / \mathrm{kg}$; copper sulfate, 7 $\mathrm{g} / \mathrm{kg}$; cobalt sulfate, $500 \mathrm{mg} / \mathrm{kg}$; potassium iodate, $500 \mathrm{mg} / \mathrm{kg}$; sodium selenite, $100 \mathrm{mg} /$ $\mathrm{kg}$ and manganese sulfate: $5 \mathrm{~g} / \mathrm{kg}$. 
Table 1

Ingredients and chemical composition of the supplement and forage used during the experiment

\begin{tabular}{|c|c|c|}
\hline Item & Supplement & Brachiaria decumbens $s^{2,3}$ \\
\hline \multicolumn{3}{|l|}{ Ingredients \% (as-feed basis) } \\
\hline Soybean meal & 22.20 & - \\
\hline Cottonseed meal & 26.80 & - \\
\hline Ground corn & 25.60 & - \\
\hline Ground wheat bran & 25.40 & - \\
\hline \multicolumn{3}{|c|}{ Chemical Composition ( $\mathrm{g} \mathrm{kg}^{-1}$ of DM) } \\
\hline Dry matter ( $\mathrm{g} \mathrm{kg}^{-1}$ of NM) & 888.2 & $255.0 \pm 5.2$ \\
\hline Organic matter & 962.8 & $921.2 \pm 4.66$ \\
\hline Crude protein & 247.7 & $107.0 \pm 4.30$ \\
\hline Ether extract & 30.7 & $20.1 \pm 1.05$ \\
\hline Non-fibrous carbohydrates & 470.7 & $244.6 \pm 18.30$ \\
\hline NDFap & 213.6 & $548.0 \pm 21.30$ \\
\hline NDIP ( $\mathrm{g} \mathrm{kg}^{-1}$ of CP) & 253.3 & $447.0 \pm 14.20$ \\
\hline iNDF & 51.0 & $102.5 \pm 6.20$ \\
\hline
\end{tabular}

$\mathrm{NM}=$ natural matter, NDFap= neutral detergent fiber corrected for ash and protein, NDIP= neutral detergent insoluble protein, iNDF= indigestible neutral detergent insoluble fiber. 2Mean values for samples obtained by hand-plucking throughout the experimental period, 3Means \pm standard error medium.

\section{Animal handling}

Animals were subjected to 14 days of adaptation to the diet and the experimental area. Animals were allocated to one of four paddocks of 2.5 hectares each, uniformly covered with Brachiaria decumbens Stapf., and equipped with covered drinkers and feeders with access from both sides to allow the simultaneous access of the animals. The supplement was given daily at $10 \mathrm{~h} 00$. Animals had unrestricted access to water during the experiment.

Throughout the experiment, the animals were weighed every 28 days without fasting in the morning to monitor performance and well-being. Animals were rotated across the paddocks every seven days to eliminate possible effects of the paddocks on the experimental treatments so that each group remained for the same period in each paddock.

\section{Forage samples}

Every fourteen days a sample was collected by the hand-plucking method to evaluate the chemical composition of the pasture consumed by the animals (Table 1). A second sample was collected every 28th day of each to quantify the total availability of dry matter (DM) and potentially digestible dry matter (pdDM). Four forage samples were randomly selected using a metal square of 0.5 $\times 0.5 \mathrm{~m}$ and by making a cut at approximately $1 \mathrm{~cm}$ above the soil. Samples were ovendried at $60^{\circ} \mathrm{C}$ for $72 \mathrm{~h}$ and ground in a Wiley 
mill (TE-650, Tecnal, Piracicaba, SP, Brasil) to pass through a 2-mm screen. After that, half of each ground sample was ground again to pass through a 1-mm screen. Samples were pooled in the experimental period.

\section{Nutritional characteristics}

To evaluate the intake and the forage digestibility, a nine-day trial was performed from the 43rd experimental day according to recommendations by Sampaio et al. (2011). The first six days of the trial were used for the adaptation ofanimals tothemarkers. Chromium oxide $\left(\mathrm{Cr}_{2} \mathrm{O}_{3}\right)$ was used as an external marker to estimate fecal excretion. This was packaged in paper cartridges in the amount of $10 \mathrm{~g}$ animal and delivered via esophagus with a metal probe once daily, at $10 \mathrm{~h} 00$. Titanium dioxide $\left(\mathrm{TiO}_{2}\right)$ was used to estimate the individual intake of the supplement, being previously mixed in the supplement at the proportion of $10 \mathrm{~g} \mathrm{~kg}^{-1}$ of supplement. The indigestible neutral detergent insoluble fiber (iNDF) was used as an internal marker to estimate forage DM intake. In the last three days of the trial, feces samples were collected immediately after defecation or directly into the rectum of animals (at amounts of approximately $200 \mathrm{~g}$ ), at different times according to the following schedule: Day 7 - 15h00, Day 8 - 11h00 and Day 9 - 07h00. Samples feces were identified, oven-dried at $60^{\circ} \mathrm{C}$ for $72 \mathrm{~h}$ and ground as previously described. After that, samples were pooled based on each animal.

On the ninth day of the trial, a spot sample of urine was collected, in spontaneous urination of the animals, and blood via jugular venipuncture, both were performed approximately four hours after the supplement was supplied. After the collection, $10 \mathrm{~mL}$ of urine were diluted in $40 \mathrm{~mL} \mathrm{H}_{2} \mathrm{SO}_{4}(0.036 \mathrm{~N})$ and frozen $\left(-20^{\circ} \mathrm{C}\right)$ to later quantify the contents of creatinine, urea, and purine derivatives. The blood samples were collected at the end of the urine collection period using vacuum tubes containing separator gel and clot accelerator (BD Vacuntainer ${ }^{\circledR}$ SST II Advance). The blood was immediately centrifuged at $2600 \times \mathrm{g}$ for $20 \mathrm{~min}$, and the serum was stored $\left(-20^{\circ} \mathrm{C}\right)$.

\section{Productive performance}

To evaluate performance, the animals were weighed at the beginning and end of the experiment, both performed after 14-hour solids fasting.

\section{Analytical procedures}

Samples of forage, feces, and supplement (processed to pass through 1-mm sieves) were analyzed according to the standard analytical procedures of the Brazilian National Institute of Science and Technology in Animal Science (INCT-CA) (Detmann et al., 2012) to $\mathrm{DM}$ (dried overnight at $105^{\circ} \mathrm{C}$; method INCT-CA No G-003/1), ash (complete combustion in a muffle furnace at $600^{\circ} \mathrm{C}$ for $4 \mathrm{~h}$; method INCT-CA number M-001/1), CP (Kjeldahl procedure; method INCT-CA number $\mathrm{N}-001 / 1)$, ether extract (Randall procedure; method INCT-CA number G-005/1), neutral detergent fiber corrected for ash and protein (NDFap; using a heat-stable $\alpha$-amylase, omitting sodium sulfite and correcting for residual ash and protein; method INCT-CA number F-002/1). The content of iNDF in samples of feces, forages, and supplement (processed to pass through 2-mm sieves) was estimated using the in situ ruminal incubation 
procedure for $288 \mathrm{~h}$ (method INCT-CA number F-008/1) described by Detmann et al. (2012).

Feces samples too were analyzed to chromium concentration using nitroperchloric digestion and atomic absorption spectrophotometry and, titanium dioxide by colorimetry (Detmann et al., 2012).

The pdDM was estimated according to the following equation described by Detmann et al. (2016):

$$
p d D M=0.98 \times(100-N D F)+(N D F-i N D F)
$$

The quantification of non-fibrous carbohydrates (NFC) was performed according to Detmann and Valadares (2010):

$$
\begin{gathered}
N F C=O M-[(\% C B-\% C P U+\% U)+\% N D F a p \\
+\% E E]
\end{gathered}
$$

where: $\mathrm{OM}=$ organic matter; $\mathrm{CPU}=$ crude protein from urea; $\mathrm{U}=$ urea; NDFap = neutral detergent insoluble fiber corrected for ash and protein.

The fecal DM excretion was estimated using the chromic oxide marker, based on the ratio between the amount of chromium supplied and its concentration in the feces. Individual supplement intake was estimated (SI) by the relation of excretion of $\mathrm{TiO}_{2}$ in feces and marker concentration in the supplement.

Dry matter intake (DMI) was estimated by using iNDF as an internal marker and calculated by the following equation:

$$
\begin{gathered}
D M I=[(\text { FE } \times \text { iNDFfeces }- \text { iNDFsupplement }) / \\
\text { iNDFforage }]+S I
\end{gathered}
$$

where FE=fecal excretion $\left(\mathrm{kg} \mathrm{day}^{-1}\right)$, iNDFfeces $=$ concentration of iNDF in the feces $\left(\mathrm{kg} \mathrm{kg}^{-}\right.$ $\left.{ }^{1}\right)$, iNDFsupplement $=$ concentration of iNDF in the supplement $\left(\mathrm{kg} \mathrm{kg}^{-1}\right)$ and iNDFforage $=$ concentration of iNDF in the forage $\left(\mathrm{kg} \mathrm{kg}^{-1}\right)$ and $\mathrm{SI}=$ supplement intake.

The quantification of apparent
digestibility coefficients (DC) of diet
components was calculated by the following
equation:

$$
D C=[(\text { Ingested }- \text { excreted }) / \text { Ingested }] \times 100
$$

Daily urinary volume was calculated using the relationship between the daily creatinine excretion (CE), taking as reference the equation proposed by Costa e Silva et al. (2012), and its concentration in the spot samples:

$$
C E\left(g^{-1}\right)=0.0345 \times B W^{0.9491}
$$

where: $\mathrm{BW}$ = body weight

Excretion of the purine derivatives in urine was calculated by the sum of the allantoin and uric acid excretions, which were obtained by the product between their concentrations in urine by the daily urinary volume. Absorbed purines were calculated from the following equation:

$$
A P=P D-0.301 \times B W 0.75 / 0.80
$$

where $\mathrm{AP}=$ absorbed purines $\left(\mathrm{mmol} \mathrm{d}^{-1}\right), \mathrm{PD}=$ excretion of purine derivatives $\left(\mathrm{mmol} \mathrm{d}^{-1}\right), 0.8$ $=$ recovered absorbed purines. The $0.301 \times$ $\mathrm{BW}^{0.75}$ value $=$ endogenous excretion of purine derivates.

Ruminal synthesis of nitrogen compounds was calculated as a function of the absorbed purines using the equation described by Barbosa et al. (2011). 


$$
N M I C=70 \times A P / 0.93 \times 0.137 \times 1.000
$$

where $\mathrm{NMIC}=$ ruminal synthesis of nitrogen compounds $\left(\mathrm{g} \mathrm{d}^{-1}\right), \mathrm{AP}=$ absorbed purines $\left(\mathrm{mmol} \mathrm{d}^{-1}\right), 70=$ purine $\mathrm{N}$ content $\left(\mathrm{mg} \mathrm{mol}^{-1}\right)$, $0.93=$ purine digestibility and $0.137=$ relation of purine $\mathrm{N}$ : total $\mathrm{N}$ of microorganisms.

The EMS was estimated by dividing protein microbial production by the DOM intake.

Serum and urine urea concentration by colorimetric kinetic method (Ref. Number K056-1, Bioclin ${ }^{\circledR}$ Quibasa, Belo Horizonte, Brazil), albumin (Ref. Number K040-1, Bioclin ${ }^{\circledR}$ Quibasa, Belo Horizonte, Brazil) and total protein (Ref. Number K031-1, Bioclin ${ }^{\circledR}$ Quibasa, Belo Horizonte, Brazil) by colorimetric method. Urinary creatinine by kinetic colorimetric method (Ref. Number K067-1, Bioclin ${ }^{\circledR}$ Quibasa, Belo Horizonte, Brazil) and urinary uric acid by enzymatic-colorimetric method (Ref. Number K139-1, Bioclin ${ }^{\circledR}$ Quibasa, Belo Horizonte, Brazil). Serum urea N (SUN) was estimated as $46.67 \%$ of total serum urea. These metabolites were analyzed in accordance with an automatic biochemistry analyzer (Mindray BS200E, Shenzhen, China).

\section{Statistical analyses}

The experiment was analyzed according to a completely randomized design. All statistical procedures were conducted using the MIXED procedure of SAS 9.4 (SAS Institute Inc., Cary, NC, USA). The intake, digestibility, production of microbial protein, SUN, average daily gain (ADG), final BW, were submitted to analysis of variance, adopting the initial body weight as covariate. Statistical significance was considered at $\mathrm{P} \leq 0.05$, and tendencies were considered at $0.05<P \leq 0.10$. The analysis of variance for the studied variables were performed according to the following mathematical model:

$$
Y_{i j}=\mu+T_{i}(0,1)+e_{(i j),}
$$

where $Y_{i j}=$ observations of the dependent variable corresponding to the use of the different supplement amounts $\mathrm{i}$ and repetition $j ; \mu=$ overall mean; $T_{i}=$ effect of the use of ith supplement amount, being 0, $1=0.0 \mathrm{~kg}$ animal $^{-1}$ day $^{-1}$ of supplement, $1.5 \mathrm{~kg}_{\text {animal }}{ }^{-1}$ day $^{-1}$ of supplement.

\section{Results and Discussion}

Mean DM and pdDM values during the experimental period were 5275 and 3766 $\mathrm{kg} \mathrm{ha}^{-1}$, respectively, with a potential forage digestibility value of $71.17 \%$. The forage samples obtained by the hand-plucking method had an average CP content of $107.0 \mathrm{~g}$ $\mathrm{kg}^{-1}$ DM (Table 1).

The voluntary intakes $\left(\mathrm{kg}\right.$ day $\left.^{-1}\right)$ of total DM, forage DM (FDM), OM, NDFap, iNDF, and digestible NDF (DNDF) were not affected $(P>0.10)$ by supplementation (Table 2). Comparing of voluntary intake relative to the BW of the animals ( $\mathrm{g} \mathrm{kg}^{-1} \mathrm{BW}$ ), no effect of supplementation was observed $(P>0.10)$ on the intakes of DM, FDM, OM, NDFap, and iNDF (Table 2).

Many of the positive effects of multiple supplementation or supplementation with nitrogen compounds on forage voluntary intake are a consequence of the increased rate of degradation and rate of passage of the fibrous compounds through the animal's digestive tract, and these have been described 
by several authors (Lazzarini et al., 2009; Sampaio et al., 2009). Nonetheless, the forage intake is determined by an integration of different mechanisms (physical limitation and metabolic feedbacks). Among the metabolic feedbacks, the adequacy of the proteinenergy ratio, represented by the CP:DOM ratio of the diet, helps to understand the metabolic effects of the protein on intake and has been pointed out as the main regulatory parameter of the intake pattern in cattle fed tropical forages (Detmann et al., 2014b). Maximum forage intake is observed with a dietary CP:DOM ratio of 216 to $288 \mathrm{~g} \mathrm{~kg}^{-1}$ (Detmann et al., 2014b; Reis et al., 2016). In the current study, the dietary CP:DOM ratio for control and supplemented animals was 173 and $198 \mathrm{~g}$ $\mathrm{kg}^{-1}$, respectively, which are lower values than those recommended by the above-mentioned authors. According to these results, both treatments showed an imbalanced dietary protein-to energy ratio, which may explain the lack of differences in the intakes of FDM, NDFap, and iNDF between treatments. A similar pattern was reported in experiments performed under tropical conditions (Batista et al., 2016; Lazzarini et al., 2016).

On the other hand, supplementation increased $(P<0.01)$ the intakes of $C P, E E$, and NFC for the animals (Table 2). Additionally, there was an upward trend $(P=0.076)$ in the intake of DOM caused by supplementation (Table 2).
The greater intake of $\mathrm{CP}, \mathrm{EE}$, and NFC observed in the supplemented animals (Table 2), can be attributed to the supply of supplement and the higher content of these components in the same (Table 1). This greater intake of $\mathrm{CP}, \mathrm{EE}, \mathrm{NFC}$ can justify the trend of increase in the intake of DOM in the supplemented animals (Table 2).

Overall, supplementation increased $(P<0.01)$ the digestibility coefficients of DM, $\mathrm{OM}, \mathrm{CP}, \mathrm{EE}$, and NFC (Table 3). However, no supplementation effect alone was seen $(P>0.10)$ on the digestibility coefficient of NDFap (Table 3). Finally, the higher digestibility of $\mathrm{CP}, \mathrm{EE}$, and NFC caused by supplementation increased $(P<0.01)$ the dietary content of DOM (Table 3).

The most prominent effects of supplementation were observed on the nutrient digestibility and productive performance of the animals. The increase in the digestibility coefficients of DM and OM with supplementation is a consequence of the inclusion of protein-energy supplements (concentrate) in the diet, which are highly digestible. 
Table 2

Voluntary intake of diet components in beef heifers under grazing of Brachiaria decumbens with $1.5 \mathrm{~kg}$ of protein-energy supplementation

\begin{tabular}{|c|c|c|c|c|}
\hline \multirow{2}{*}{ Item } & \multicolumn{2}{|c|}{ Treatments } & \multirow{2}{*}{ SEM } & \multirow{2}{*}{ P-Value } \\
\hline & Control & Supplemented & & \\
\hline \multicolumn{5}{|c|}{$\mathrm{kg} \mathrm{day}^{-1}$} \\
\hline DM & 5.20 & 6.26 & 0.570 & 0.219 \\
\hline DMF & 5.20 & 4.93 & 0.570 & 0.740 \\
\hline DMS & - & 1.33 & - & - \\
\hline $\mathrm{OM}$ & 4.79 & 5.81 & 0.525 & 0.197 \\
\hline $\mathrm{CP}$ & 0.53 & 0.83 & 0.058 & 0.003 \\
\hline EE & 0.11 & 0.16 & 0.013 & 0.018 \\
\hline NDFap & 3.01 & 3.02 & 0.320 & 0.982 \\
\hline NFC & 1.14 & 1.80 & 0.133 & 0.005 \\
\hline iNDF & 0.56 & 0.60 & 0.062 & 0.672 \\
\hline DOM & 3.04 & 4.21 & 0.419 & 0.076 \\
\hline DNDF & 2.11 & 2.17 & 0.256 & 0.857 \\
\hline \multicolumn{4}{|c|}{$\mathrm{g} \mathrm{kg}^{-1}$ of $\mathrm{BW}$} & 253.3 \\
\hline DMS & 20.0 & 22.4 & 1.86 & 0.374 \\
\hline DMF & 20.0 & 17.6 & 1.88 & 0.403 \\
\hline $\mathrm{OM}$ & 18.4 & 20.8 & 1.72 & 0.337 \\
\hline iNDF & 2.2 & 2.2 & 0.20 & 0.986 \\
\hline
\end{tabular}

$\mathrm{DM}=$ dry matter, $\mathrm{DMF}=$ dry matter from forage, $\mathrm{DMS}=$ dry matter from supplement, $\mathrm{OM}=$ organic matter, $\mathrm{CP}=\mathrm{crude}$ protein, $\mathrm{EE}=$ ether extract, NDFap= neutral detergent insoluble fiber corrected for ash and protein, NFC= non-fibrous carbohydrates, iNDF= indigestible neutral detergent insoluble fiber, DOM= digested organic matter, DFDN= digestible neutral detergent insoluble fiber.

The greater digestibility of $\mathrm{CP}$ in supplemented animals in relation to the control group may be attributed to the higher intake of CP (Table 2), which allows lower participation of the endogenous protein and reduces the representativeness of the fecal metabolic fraction of the nitrogen compounds (Ortega et al., 2020). By contrast, the negative EE digestibility of the forage observed in the animals of the controlgroupwasa consequence of the low EE levels consumed (forage), which was below the fecal metabolic contribution. In its turn, the higher digestibility coefficients of EE and NFC of the forage observed in the supplemented animals are associated with the higher intake of these constituents from the supply of supplement, which was above the fecal metabolic contribution (Table 3). Thus, the higher digestibility of $\mathrm{CP}, \mathrm{EE}$, and NFC of the forage in the supplemented animals can be supported by the higher dietary content of DOM (Table 3).

This result may be associated with the $\mathrm{CP}$ content of the forage (Table 1) that was higher to promote of microbial growth on fiber (70-80 g CP kg-1 DM) (Sampaio et al., 2009) and 
close to the level necessary to maximize the voluntary forage intake (90-100 $\mathrm{g} \mathrm{CP} \mathrm{kg}^{-1} \mathrm{DM}$ ) (Detmann et al., 2014a). From this level of CP in the diet, the nitrogenous requirements of the ruminal microorganisms are met and benefits on forage degradation are not observed.

Table 3

Apparent digestibility coefficients of diet components in beef heifers under grazing of Brachiaria decumbens with $1.5 \mathrm{~kg}$ of protein-energy supplementation

\begin{tabular}{|c|c|c|c|c|}
\hline \multirow{2}{*}{ Item } & \multicolumn{2}{|c|}{ Treatments } & \multirow{2}{*}{ SEM } & \multirow{2}{*}{ P-Value } \\
\hline & Control & Supplemented & & \\
\hline \multicolumn{5}{|c|}{$\mathrm{g} \mathrm{kg}^{-1}$} \\
\hline Dry matter & 582.7 & 666.1 & 0.0090 & $<0.001$ \\
\hline Organic matter & 633.4 & 720.6 & 0.0109 & $<0.001$ \\
\hline Crude protein & 452.8 & 638.8 & 0.0182 & $<0.001$ \\
\hline Ether extract & -385.4 & 310.6 & 0.0574 & $<0.001$ \\
\hline FDNap & 697.0 & 713.3 & 0.0090 & 0.229 \\
\hline NFC & 644.9 & 806.6 & 0.0224 & $<0.001$ \\
\hline \multicolumn{5}{|c|}{$\mathrm{g} \mathrm{kg}^{-1}$ of DM } \\
\hline DOM & 583.3 & 669.9 & 9.90 & $<0.001$ \\
\hline
\end{tabular}

NDFap $=$ neutral detergent insoluble fiber corrected for ash and protein, NFC= non-fibrous carbohydrates, DOM= digested organic matter.

No supplementation effect was detected $(P>0.10)$ on MICN, EMS, RMICN, or UUN (Table 4). An effect of supplementation alone was observed $(\mathrm{P}<0.01)$ on SUN (Table 4$)$.

Microbial growth is influenced by the availability of essential nutrients required by rumenmicroorganisms, suchascarbohydrates, ammonia, peptides, amino acids, sulfur, and branched-chain fatty acids (Ortega et al., 2020). Therefore, the supplemented animals were expected to show a higher MICN than animals in the control group (Table 4), but this behavior is not always observed. This apparently contradicts the arguments presented here for intake and digestibility, which are based on the improvement of the rumen environment associated with the increase in the concentration of nitrogen compounds. This behavior has also been observed by other authors (Lazzarini et al., 2009).

The EMS for control and supplemented animals was 131.6 and $121.2 \mathrm{~g} \mathrm{CP} \mathrm{kg}^{-1}$, respectively. These results are similar to those observed by Ortega et al. (2016) in heifers under grazing. Besides, despite the higher $\mathrm{CP}$ intake by the supplemented animals (Table 2) compared with the control group, no difference was observed in RMICN across treatments (Table 4). According to Detmann et al. (2014a), estimates of RMICN greater than 1 indicate a severe deficiency of nitrogen compounds and a much greater dependence on nitrogen recycling to maintain the growth of ruminal 
microorganisms. According to the above authors, it could be inferred that there were no deficiencies of nitrogenous compounds in the rumen in the animals of both treatments. However, Detmann et al. (2014b) suggested that it should be noted that, under tropical conditions, a RMICN lower than 1 does not ensure a good nitrogen status in the rumen itself, because an excessive gain of nitrogen through recycling could still be occurring and a non-optimized condition would not be avoided as soon as nitrogen became available in metabolism. Thus, animals in the control group possibly exhibited deficiencies of nitrogen compounds inasmuch as they had a RMICN closer to 1 (Table 4).

The SUN is employed to diagnose the efficiency of use of nitrogen compounds in the rumen according to the availability of degradable protein (Sampaio et al., 2009). As stated by Broderick and Clayton (1997), the concentration of SUN is positively associated with the intake of $\mathrm{CP}$, rumen degradable protein, and rumen ammonia concentration. The optimal SUN concentration in heifers varies from 11 to $15 \mathrm{mg} \mathrm{dL}^{-1}$ (Byers \& Moxon, 1980). Thus, the higher SUN concentration of the supplemented group compared with control animals may be attributed to the higher CP intake of the former (Table 2).

The UUN excretion is positively related to the concentration of SUN and CP intake (Ortega et al., 2020). Similar UUN excretions between treatments associated with the higher CP intake by the supplemented animals indicate a better utilization efficiency of the nitrogen consumed compared with the animals of the control group.

\section{Table 4}

Nitrogen levels in beef heifers under grazing of Brachiaria decumbens with $1.5 \mathrm{~kg}$ of protein-energy supplementation

\begin{tabular}{|c|c|c|c|c|}
\hline \multirow{2}{*}{ Item } & \multicolumn{2}{|c|}{ Treatments } & \multirow{2}{*}{ SEM } & \multirow{2}{*}{ P-Value } \\
\hline & Control & Supplemented & & \\
\hline NMIC $\left(\mathrm{g} \mathrm{d}^{-1}\right)$ & 63.0 & 75.1 & 11.81 & 0.483 \\
\hline RMICN $\left(\mathrm{g} \mathrm{g} \mathrm{N}^{-1}\right)$ & 0.751 & 0.592 & 0.1206 & 0.371 \\
\hline EMS (g CP kg-1 MOD) & 131.6 & 121.2 & 24.95 & 0.772 \\
\hline SUN (mg dL-1) & 9.9 & 17.0 & 1.10 & 0.001 \\
\hline UUN $\left(\mathrm{g} \mathrm{d}^{-1}\right)$ & 39.2 & 41.4 & 3.41 & 0.658 \\
\hline
\end{tabular}

$\mathrm{MICN}=$ production of microbial nitrogen compounds, $\mathrm{RMICN}=$ relative microbial nitrogen, $\mathrm{EMS}=$ efficiency of microbial protein synthesis, $\mathrm{SUN}=$ serum urea nitrogen, $\mathrm{UUN}=$ urea nitrogen excretion in the urine.

Supplementation increased $(P=0.050)$ the ADG of the animals (Table 5). Nevertheless, no effect of supplementation was observed $(P=0.279)$ on the final BW (FBW) of the animals (Table 5).
The higher ADG of supplemented animals compared with the control group (Table 5) may be due to the inclusion of multiple supplements (easy digestion) in the diet and to the higher intakes of $\mathrm{CP}, \mathrm{EE}, \mathrm{NFC}$, 
and DOM by the supplemented animals. Similarly, researchers conducting studies in tropical conditions reported higher ADG in supplemented animals compared with unsupplemented animals (Cabral et al., 2014; Ortega et al., 2016).

\section{Table 5}

Productive performance in beef heifers under grazing of Brachiaria decumbens with $1.5 \mathrm{~kg}$ of proteinenergy supplementation

\begin{tabular}{|c|c|c|c|c|}
\hline \multirow{2}{*}{ Item } & \multicolumn{2}{|c|}{ Treatments } & \multirow{2}{*}{ SEM } & \multirow{2}{*}{ P-Value } \\
\hline & Control & Supplemented & & \\
\hline ADG (kg day $\left.{ }^{-1}\right)$ & 0.167 & 0.353 & 0.0597 & 0.050 \\
\hline FBW (kg) & 268.2 & 277.8 & 5.80 & 0.279 \\
\hline
\end{tabular}

$A D G=$ average daily gain, $F B W=$ final body weight.

\section{Conclusions}

In summary, it is concluded that the protein-energy supplementation of grazing beef heifers improves the productive performance and nutritional characteristics.

\section{Acknowledgements}

The authors thank to Foundation for Research Support of the State of Minas Gerais (FAPEMIG) for project funding.

\section{Conflict of interest}

We certify that there is no conflict of interest with any financial organization regarding the material discussed in the manuscript.

\section{References}

Almeida, D. M. de, Marcondes, M. I., Rennó, L. N., Silva, L. H. P., Martins, L. S., Marquez,
D. E. C.,... Paulino, M. F. (2018). Nutritional planning for Nellore heifers post-weaning to conception at 15 months of age: performance and nutritional, metabolic, and reproductive responses. Tropical Animal Health and Production, 51(8), 7987. doi: 10.1007/s11250-018-1662-z

Barbosa, A. M., Valadares, R. F. D., Valadares, S. C., Fo., Pina, D. S., Detmann, E., \& Leão, M. I. (2011). Endogenous fraction and urinary recovery of purine derivatives obtained by different methods in Nellore cattle. Journal of Animal Science, 89(2), 510-519. doi: 10.2527/jas.2009-2366

Batista, E. D., Detmann, E., Titgemeyer, E. C., Valadares, S. C., Fo., Valadares, R. F. D., Prates, L. L.,... Paulino, M. F. (2016). Effects of varying ruminally undegradable protein supplementation on forage digestion, nitrogen metabolism, and urea kinetics in Nellore cattle fed low-quality tropical forage. Journal of Animal Science, 94(1), 201-216. doi: 10.2527/jas.2015-9493

Broderick, G. A., \& Clayton, M. K. (1997). A statistical evaluation of animal and nutritional factors influencing concentrations of milk urea nitrogen. 
Journal of Dairy Science, 80(11), 29642971. doi: 10. 3168/jds.S0022-0302(97) $76262-3$

Byers, F. M., \& Moxon, A. L. (1980). Protein and selenium levels for growing and finishing beef cattle. Journal of Animal Science, 50(6), 1136-1144. doi: 10.2527/ jas1980.5061136x

Cabral, C. H. A., Paulino, M. F., Detmann, E., Valadares, S. C., Fo., Barros, L. V., Valente, É. E. L.,... Cabral, C. E. A. (2014). Levels of supplementation for grazing beef heifers. Asian-Australasian Journal of Animal Science, 27(6), 806-817. doi: 10.5713/ ajas.2013.13542

Costa e Silva, L. F., Valadares, S. C., Fo., Chizzotti, M. L., Rotta, P. P., Prados, L. F., Valadares, R. F. D.,... Braga, J. M. S. (2012). Creatinine excretion and relationship with body weight of Nellore cattle. Revista Brasileira de Zootecnia, 4(3), 807-810. doi: 10.1590/ S1516-35982012000300046

Detmann, E., \& Valadares, S. C., Fo. (2010). On the estimation of non-fibrous carbohydrates in feeds and diets. Arquivo Brasileiro de Medicina Veterinária e Zootecnia, 62(4), 980-984. doi: 10.1590/S0102-09352010 000400030

Detmann, E., Souza, M. A. de, Valadares, S. C., Fo., de Queiroz, A. C., Berchielli, T. T., Cabral, L. S.,... Acevedo, J. A. G. (2012). Métodos para análise de alimentos INCT - ciência animal. Visconde do Rio Branco, MG: Suprema Gráfica. Retrieved from https://www. editoraufv.com.br/produto/metodospara-analise-de-alimentos/1109316

Detmann, E., Gionbelli, M. P., Paulino, M. F., Valadares, S. C., Fº., \& Rennó, L. N. (2016). Considerations on research methods applied to ruminants under grazing. Nutri Time Revista Eletrônica, 13(3), 4711-4731.
Retrieved from https://www.nutritime.com. br/site/artigo-381-consideracoes-sobremetodos-de-pesquisa-com-ruminantesem-pastejo/

Detmann, E., Paulino, M. F., Valadares, S. C., Fo., \& Huhtanen, P. (2014a). Nutritional aspects applied to grazing cattle in the tropics: a review based on Brazilian results. Semina: Ciências Agrárias, 35(4), 2829-2854. doi: 10.5433/16790359.2014v35n4Suplp28 29

Detmann, E., Valente, É. E. L., Batista, E. D., \& Huhtanen, P. (2014b). An evaluation of the performance and efficiency of nitrogen utilization in cattle fed tropical grass pastures with supplementation. Livestock Science, 162(1), 141-153. doi: 10.1016/j. livsci.2014.01.029

Lazzarini, I., Detmann, E., Sampaio, C. B., Paulino, M. F., Valadares, S. C., Fo., Souza, M. A., \& Oliveira, F. A. (2009). Intake and digestibility in cattle fed low-quality tropical forage and supplemented with nitrogenous compounds. Revista Brasileira de Zootecnia, 38(10), 2021-2030. doi: 10.1590/S1516-3598 2009001000024

Lazzarini, Í., Detmann, E., Valadares, S. C., Fo., Paulino, M. F., Batista, E. D., Rufino, L. M. A.,... Franco, M. O. (2016). Nutritional performance of cattle grazing during rainy season with nitrogen and starch supplementation. Asian-Australasian Journal of Animal Science, 29(8), 1120. doi: 10.5713/ajas.15.0514

Ortega, R. M., Paulino, M. F., Detmann, E., Rennó, L. N., Silva, A. G. da, Marquez, D. C.,... Bitencourt, J. A. (2016). Quantities of supplements for grazing beef heifers in the dry-rainy transition season. Semina: Ciências Agrárias, 37(1), 461-472. doi: 10.5433/1679-0359.2016v37n1p461 
Ortega, R. M., Paulino, M. F., Detmann, E., Rennó, L. N., Sotelo, D. M., Marquez, D. C.,... Ramalho, T. (2020). Supplementation levels for suckling female calves under grazing: productive and nutritional performance and metabolic profile. Semina: Ciências Agrárias, 41(3), 945-958. doi: 10.5433/1679-0359.2020v41n3p945

Reis, W. L. S., Detmann, E., Batista, E. D., Rufino, L. M. A., Gomes, D. I., Bento, C. B. P.,... Valadares, S.C., Fo. (2016). Effects of ruminal and post-ruminal protein supplementation in cattle fed tropical forages on insoluble fiber degradation, activity of fibrolytic enzymes, and the ruminal microbial community profile. Animal Feed Science and Technology, 218(8), 1-16. doi: 10. 1016/j.anifeedsci.2016.05.001
Sampaio, C. B., Detmann, E., Valente, T., Costa, V., Valadares, S. C., Fo., \& Queiroz, A. (2011). Fecal excretion patterns and short term bias of internal and external markers in a digestion assay with cattle. Revista Brasileira de Zootecnia, 40(3), 657-665. doi: 10.1590/S1516-35982011000300026

Sampaio, C. B., Detmann, E., Lazzarini, I., Souza, M. A., Paulino, M. F., \& Valadares, S. C., Fo. (2009). Rumen dynamics of neutral detergent fiber in cattle fed lowquality tropical forage and supplemented with nitrogenous compounds. Revista Brasileira de Zootecnia, 38(3), 560-569. doi: 10.1590/S1516-35982009000300023 